\title{
PEMBERDAYAAN MASYARAKAT DALAM PENGOLAHAN LIMBAH KULIT BUAH MANGGIS (Garcinia mangostana L) DI DESA LINGSAR KEC. LINGSAR KAB. LOMBOK BARAT
}

\author{
Nurdiana \\ Institut Agama Islam Negeri Mataram \\ Email: drdianana@gmail.com
}

\begin{abstract}
Abstrak: Sampah dan limbah merupakan permasalahan lingkungan yang harus diminimalisir. Permasalahan yang dihasilkan diantaranya seperti merusak pemandangan, bau, dan mencemari lingkungan. Salah satu kegiatan yang dapat menghasilkan sampah dan limbah adalah aktivitas belajar mengajar di madrasah. Seperti di Madrasah Binaan IAIN Mataram yaitu Madrasah NW Mercapada Selat Narmada Lombok Barat Nusa Tenggara Barat Indonesia. Tujuan dalam kegiatan Pengabdian Masyarakat adalah; untuk memperagakan/mempraktikan proses/cara pengolahan sampah dan limbah yang dihasilkan dalam proses kegiatan belajar mengajar di Madrasah Aliyah NW Mercapada Selat Narmada Kabupaten Lombok Barat dan untuk mengetahui kondisi lingkungan Madrasah NW Mercapada Selat Narmada, sehingga perlu dilakukan pelatihan manajemen sampah dan limbah. Langkah yang dapat dilakukan untuk meminimalisir jumlah sampah dari kegiatan belajar mengajar tersebut adalah dengan meningkatkan kualitas Sumberdaya Manusia seperti peserta didik, tenaga pendidik dan pengelola madrasah. Pelatihan manajemen sampah dan limbah mampu menghasilkan produk, baik berupa kerajinan tangan berbahan dasar sampah plastik, kompos, dan pupuk organik cair maupun padat. Hasil kegiatan pengabdian dapat memberikan solusi dalam menghadapi permasalahan lingkungan yang terjadi terutama permasalahan lingkungan yang terjadi di lingkungan madrasah seperti permasalahan sampah dan limbah yang dihasilkan selama kegiatan belajar mengajar.
\end{abstract}

Kata kunci: Sampah, Limbah dan Lingkungan

\section{PENDAHULUAN}

Madrasah merupakan salah satu lembaga pendidikan yang ada di Indonesia dan dapat dikatakan sebagai salah satu lembaga pendidikan tertua (Sejarah Pendidikan Indonesia yang dimulai dari Pondok Pesantren). Madrasah bernaung di bawah pimpinan Kementerian Agama. Diharapkan lulusan atau output yang dihasilkan dari lembaga pendidikan yang dinamakan madrasah ini dapat menjadi orang-orang atau masyarakat yang mampu menyeimbangkan kehidupan dunia dan kehidupan akhirat sehingga terbentuk harmoni (Hablumminalloh, wa hablumminannas, wa hablumninal alam).

Harmoni kehidupan ber-agama atau keseimbangan hidup akan membuat jiwa menjadi tenang "dengan mengingat Allah, hati akan menjadi tenang" sehingga segala aktivitas yang dilaksanakan akan selalu dipertimbangkan matang-matang 
karena akibat atau dampak yang ditimbulkan. Inilah salah satu yang diinginkan madrasah kepada para peserta didik agar memiliki akhlak karimah (sifat yang baik) sehingga dapat menjadi cerminan hidup di dalam bermasyarakat.

Potret lingkungan hidup saat ini yang tertuju kepada arah Hedonisme dan Antroposentrisme menyebabkan lingkungan (Ekosentrisme) ter-abaikan. Sehingga bencana alam yang tidak diinginkan terjadi di berbagai daerah di nusantara. Bencana alam yang terjadi pada tahun-tahun belakangan ini antara lain banjir, longsor, gunung meletus, kekeringan, kebakaran hutan, kabut asap, dan gempa bumi (bencana langganan di negeri ini). Sebagaimana firman Allah SWT dalam Qs. Ar-Rum (30) ayat 44 yang berbunyi:

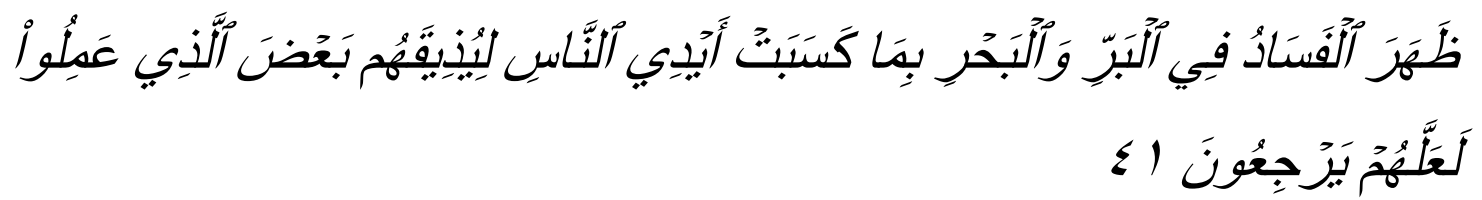

"Telah nampak kerusakan di darat dan di laut disebabkan karena perbuatan tangan manusia, supaya Allah merasakan kepada mereka sebahagian dari (akibat) perbuatan mereka, agar mereka kembali (ke jalan yang benar)".

Kualitas lingkungan hidup yang semakin menurun telah mengancam kelangsungan perikehidupan manusia dan makhluk hidup lainnya sehingga perlu dilakukan perlindungan dan pengelolaan lingkungan hidup yang sungguh-sungguh dan konsisten oleh semua pemangku kepentingan. Perlindungan dan pengelolaan lingkungan hidup adalah upaya sistematis dan terpadu yang dilakukan untuk melestarikan fungsi lingkungan hidup dan mencegah terjadinya pencemaran dan/atau kerusakan lingkungan hidup yang meliputi perencanaan, pemanfaatan, pengendalian, pemeliharaan, pengawasan dan penegakan hukum (UU RI No. 32 tahun 2009). Hal ini berlaku juga pada sampah dan limbah yang dihasilkan dalam sebuah kegiatan belajar mengajar di madrasah. Contohnya di Madrasah NW Mercapada Selat narmada.

Dari kondisi inilah yangmelatar belakangi pengabdian masyarakat dengan judul " Pelatihan Manajemen Sampah dan Limbah yang dihasilkan dalam Aktivitas Belajar mengajar di Madrasah Aliyah NW Selat Narmada Lombok Barat NTB" 
Transformasi, Vol. 12, No. 2, Juli 2016: 186-197

\section{PEMBAHASAN}

\section{Lingkungan}

Lingkungan adalah suatu sistem kompleks yang berada di luar individu yang mempengaruhi pertumbuhan dan perkembangan organisme. Lingkungan tidak sama dengan habitat. Habitat adalah tempat dimana organisme atau komunitas organisme hidup (Setyono, 2008)

Lingkungan merupakan sistem terintegrasi antar komponen abiotik dan biotik yang keduanya berada pada kondisi hubungan kompensatif dan menghasilkan keharmonisan sistem. Lingkungan merupakan sistem yang di dalamnya bekerja subsistem-subsistem baik subsistem abiotik maupun biotik dan berlangsungnya proses alih rupa (transformation) dan alih tempat (translocation) yang dipicu oleh proses pertukaran energi dan bahan/materi antar subsistem tersebut. Subsistem abiotik meliputi atmosfer, pedhosfer/lithosfer dan hidrosfer, sedangkan subsistem biotik merupakan semua makhluk hidup atau organisme dengan seluruh bentuk interaksi yang terjadi (Budiastuti, 2010).

Dalam buku Teologi Lingkungan (Kementerian Lingkungan Hidup, 2011) lingkungan sebagai suatu keadaan atau kondisi alam yang terdiri atas benda-benda (makhluk) hidup dan benda-benda tak hidup yang berada di bumi atau bagian dari bumi secara alami dan saling berhubungan antara satu dengan lainnya.

Komponen Lingkungan

1. Lingkungan abiotik

Lingkungan abiotik adalah segala benda mati dan keadaan fisik yang ada di sekitar individu-individu misalnya: batu-batuan, mineral, udara, unsur-unsur iklim, cuaca, suhu, kelembaban angin, faktor gaya berat dan lain-lain (fisik) (Budiastuti, 2010). Sedangkan dalam (Ginting, 2007) meliputi BOD, COD, pH (kimia).

2. Lingkungan biotik

Lingkungan biotik adalah segala mahluk hidup yang ada di sekitar individu baik tumbuh-tumbuhan, hewan dan manusia. Tiap unsur ini berinteraksi antar biotik dan juga dengan lingkungan fisik atau abiotik. Lingkungan biotik meliputi produsen, konsumen, dan dekomposer (Budiastuti, 2010).

3. Budaya 
Budaya adalah suatu tradisi yang terbentuk karena kebiasaan yang turun temurun. Tradisi berasal dari bahasa latin tradition, yang berarti kebiasaan atau diteruskan. Pengertian tradisi adalah sesuatu yang dilakukan sejak lama dan menjadi bagian kehidupan suatu komunitas atau kelompok masyarakat (Rohadi, 2011).

\section{Macam-Macam Lingkungan}

1. Lingkungan Hidup Alami

Lingkungan hidup alami adalah lingkungan hidup yang belum terkena campur tangan manusia atau mengalami modifikasi oleh manusia. Dalam lingkungan seperti ini, manusialah yang melakukan adaptasi sepenuhnya, disesuaikan dengan keadaan alam. Lingkungan yang belum dimodifikasi oleh manusia itu memiliki kecenderungan mantap dan seimbang.

2. Lingkungan Hidup Binaan

Lingkungan hidup binaan adalah lingkungan hidup yang dikelola, dimodifikasi, dibentuk dan ditentukan keadaannya oleh manusia dengan menggunakan daya nalar, akar, budi, ilmu dan teknologi serta sistem sosial, budaya, dan ekonomi. Tujuan dibentuknya lingkungan hidup binaan adalah efisiensi dan efektivitas pemanfaatan sumber daya alam dan lingkungan oleh manusia. Karakteristik dari lingkungan ini adalah menonjolnya dampak teknologi dan budaya, keadaan lingkungan cenderung tidak mantap (perlu adanya subsidi energi) akibat adanya aktivitas manusia, komponen biotik dan nonbiotik cenderung tidak seimbang atau labil. Contoh lingkungan hidup binaan adalah daerah pertanian, dan peternakan.

3. Lingkungan Hidup Sosial

Lingkungan hidup sosial merupakan kesatuan ruang dengan sejumlah manusia yang hidup berkelompok sesuai dengan suatu keteraturan sosial dan kebudayaan bersama.

\section{Asas-Asas Lingkungan}

Asas-asas lingkungan diantaranya adalah hukum termodinamika pertama atau yang disebut hukum konservasi energi. Energi dapat berubah dari suatu bentuk ke bentuk lain, tetapi tidak dapat dihancurkan atau diciptakan. Energi yang 
memasuki organisme hidup, populasi atau ekosistem dapat dianggap sebagai energi yang tersimpan atau terlepaskan. Sistem kehidupan dapat dianggap sebagai pengubah energi. Ada berbagai strategi untuk mentransformasikan energi. Jika ada pembukuan ke luar masuk uang dalam perusahaan, maka sebaiknya ada pembukuan kalori dalam sistem kehidupan (Setyono, 2008).

Asas kedua diambil dari hukum termodinamika kedua, yakni tidak ada sistem pengubahan energi yang betul-betul efisien. Jadi meskipun energi itu tidak pernah hilang di alam ini, tetapi energi itu akan terus diubah ke dalam bentuk yang kurang bermanfaat. Misalnya energi yang masuk kedalam tubuh organisme berbentuk bahan makanan yang padat dan bermanfaat, sedangkan energi yang keluar dari tubuh hewan berbentuk panas (Setyono, 2008).

Asas ketiga menyangkut sumber alam. Materi, energi, ruang, waktu dan keanekaragaman semuanya termasuk kategori sumber alam. Pengubahan energi oleh sistem biologi diharapkan berlangsung pada kecepatan yang sebanding dengan materi dan energi yang ada di alam lingkungannya (Setyono, 2008). Asas keempat dinamakan asas penjenuhan, yaitu kemampuan lingkungan habitat untuk menyokong suatu materi ada batasnya. Kemampuan untuk menyokong pencemar ada batasnya. Asas kelima menyangkut pengaturan populasi dengan faktor ketergantungan pada kepadatan. Pada asas ini terangkut situasi sumber alam yang tidak menimbulkan rangsangan penggunaan lebih lanjut.

Asas keenam menyangkut persaingan. Individu dan spesies yang mempunyai lebih banyak keturunan daripada saingannya cenderung berhasil mengalahkan saingannya. Asas ketujuh menyangkut keteraturan yang pasti dalam suatu lingkungan dalam periode relatif lama. Ada fluktuasi penurunan dan kenaikan kondisi lingkungan disemua habitat, tingkat kesukaran diramalkan berbeda-beda (Setyono, 2008).

Asas kedelapan menyangkut habitat dan keanekaragaman takson. Kelompok taksonomi tertentu suatu jasad hidup ditandai keadaan lingkungan yang khas, disebut nicia. Asas kesembilan berbunyi keanekaragaman sebanding dengan biomassa atau produktivitas. Konsep kestabilan selalu diikuti dengan keanekaragaman yang tinggi sehingga rantai makanan terbentuk stabil dengan komponen biotik yang lengkap. Hal ini mempengaruhi peningkatan produktivitas. 
Asas kesepuluh berbunyi biomassa atau produktivitas meningkat dalam lingkungan yang stabil. Lingkungan yang stabil merupakan representasi aliran energi yang dinamis menurut kesetimbangan yang tertoleransi sehingga fluktuasi kuantitas biomassa dan produktivitas meningkat. Asas kesebelas berbunyi sistem yang sudah mantab (dewasa) mengeksploitasi sistem yang belum mantab. Tingkat makanan, populasi atau ekosistem yang sudah dewasa memindahkan, energi, biomassa dan keanekaragaman tingkat energi kearah yang belum dewasa (Setyono, 2008).

Asas keduabelas lahir dari asas keenam dan ketujuh. Kalau seleksi berlaku, tetapi keanekaragaman meningkat dilingkungan mantap, akan ada perbaikan sifat adaptasi terhadap lingkungan. Asas ketigabelas adalah perkembangan asas ketujuh, Sembilan dan duabelas. Asas keempatbelas berbunyi derajat pola keteraturan fluktuasi populasi bergantung kepada pengaruh sejarah populasi sebelumnya.

\section{Pencemaran Lingkungan}

Pencemaran lingkungan adalah peristiwa masuknya zat kimia, unsur, energi dan komponen-komponen yang bersifat merugikan ke dalam lingkungan sebagai akibat perbuatan manusia atau dari alam. Pencemaran lingkungan salah satunya bersumber dari limbah rumah tangga seperti perumahan, daerah perdagangan, perkantoran, dan tempat rekreasi (Setyono, 2008).

Cara Penanggulangan Pencemaran Lingkungan, antara lain;

1. Pencemaran air

Air merupakan komponen abiotik yang mutlak diperlukan oleh semua mahluk hidup, termasuk manusia. Bagi manusia, air berguna untuk minum, masak dan berbagai jenis kebutuhan lainnya. Namun, air yang sudah tercampur sudah tidak layak digunakan untuk memenuhi kebutuhan hidup. Air tercampur biasanya dapat dilihat dari warnanya yang tidak bening, berasa, dan berbau. Sumber-sumber pencemaran air dapat berupa limbah industri, limbah rumah tangga dan limbah pertanian (Sastrawijaya, 2009).

Indikator atau tanda bahwa air lingkungan telah tercemar adalah adanya perubahan atau tanda yang dapat diamati melalui; adanya perubahan suhu air, adanya perubahan ph atau kosentrasi ion hidrogen, adanya perubahan warna, 
Transformasi, Vol. 12, No. 2, Juli 2016: 186-197

bau dan rasa air, timbulnya endapan, koloid, bahan larut, adanya mikroorganisme, meningkatnya radiktivitas air lingkungan

2. Pencemaran udara

Udara terdiri atas berbagai campuran gas yang terdapat pada lapisan yang mengelilingi bumi. Komposisi udara kering yang telah dihilangkan uap airnya relatif lebih konstan. Tanpa udara, suhu akan mengalami fluktuasi, antara $110^{\circ} \mathrm{C}$ pada siang hari dan $-185^{\circ} \mathrm{C}$ pada malam hari (Sastrawijaya, 2009).

3. Pencemaran tanah

Tanah merupakan lapisan kerak bumi yang paling atas, dimana terbentuk dari batu-batuan, mineral serta makhluk hidup yang telah dihancurkan oleh mikroorganisme dan merupakan tempat kehidupan tumbuh-tumbuhan yang sangat dibutuhkan manusia sebagai sumber makanan, obat-obatan dan lain-lain.

Pencemaran tanah dapat terjadi melalui 2 cara:

a. Faktor internal. Pencemaran yang disebabkan oleh peristiwa alam, seperti letusan gunung berapi yang memuntahkan debu, batu dan bahan-bahan vulkanik lainnya yang menutupi dan merusak tanah hingga tanah menjadi tercemar.

b. Faktor eksternal. Pencemaran daratan karena ulah dan aktivitas manusia. Salah satu contohnya adalah pencemaran yang diakibatkan oleh limbah industri (Sastrawijaya, 2009)

c. Faktor-faktor yang mempengaruhi pencemaran lingkungan. Faktor-faktor yang mempengaruhi pencemaran air; Bahan buangan padat, Bahan buangan organik, Bahan buangan anorganik, Bahan buangan olahan bahan makanan, Bahan buangan cairan berminyak, Bahan buangan zat kimia, Faktor-faktor yang mempengaruhi pencemaran udara. Secara umum faktor yang mempengaruhi udara ada 2 macam, yaitu:

1) Faktor internal(secara alamiah), contohnya:

(a) Debu yang berterbangan akibat tiupan angin

(b) Abu (debu) yag dikeluarkan akibat tiupan angin

(c) Proses pembusukan sampah

2) Faktor eksternal (karena ulah manusia)

(a) Hasil pembakaran bahan bakar fosil

(b) Debu/serbuk dari kegiatan industri. 
(c) Pemakaian zat-zat kimia yang disampaikan ke udara

Pencemaran daratan relatif mudah diamati (dikontrol) dibandingkan dengan pencemaran udara maupun pencemaran air, secara garis besar pencemaran daratan dapat dipengaruhi oleh:

1. Faktor internal yaitu: pencemaran yang disebabkan oleh pristiwa alam, seperti letusan gunung berapi yang menutupi dan merusak daratan sehingga daratan menjadi tercemar.

2. Faktor eksternal yaitu: pencemaran daratan karena ulah manusia dan aktivitas manusia.

\section{Cara penanggulangan pencemaran lingkungan}

Usaha untuk mengurangi dan menanggulangi pencemaran lingkungan ada dua macam cara utama yaitu;

1. Penanggulangan secara Non-teknis

Penanggualangan pencemaran dengan Non-teknis yaitu: suatu usaha untuk mengurangi dan menanggulangi pencemaran lingkungan dengan cara menciptakan peraturan perundang-undangan yang dapat merencanakan, mengatur dan mengawali segala macam bentuk kegiatan industri dan teknologi sedemikian rupa sehingga tidak terjadi pencemaran lingkungan.

2. Penanggulangan secara teknis

Kriteria yang digunakan dalam memilih dan menentukan cara yang akan digunakan dalam penanggulangan secara teknis tergantung pada faktor berikut: Mengutamakan keselamatan lingkungan, Teknologi telah dikuasai dengan baik, Secara teknis dan ekonomis dapat dipertanggung jawabkan.

Berdasarkan kriteria dapat diperoleh beberapa cara dalam hal penanggulangannya secara teknis, antara lain; Mengubah proses, Mengganti sumber energi, Mengelola limbah, Menambah alat bantu. 


\section{Proses Pelaksanaan Kegiatan/Kerangka Pemecahan Masalah}

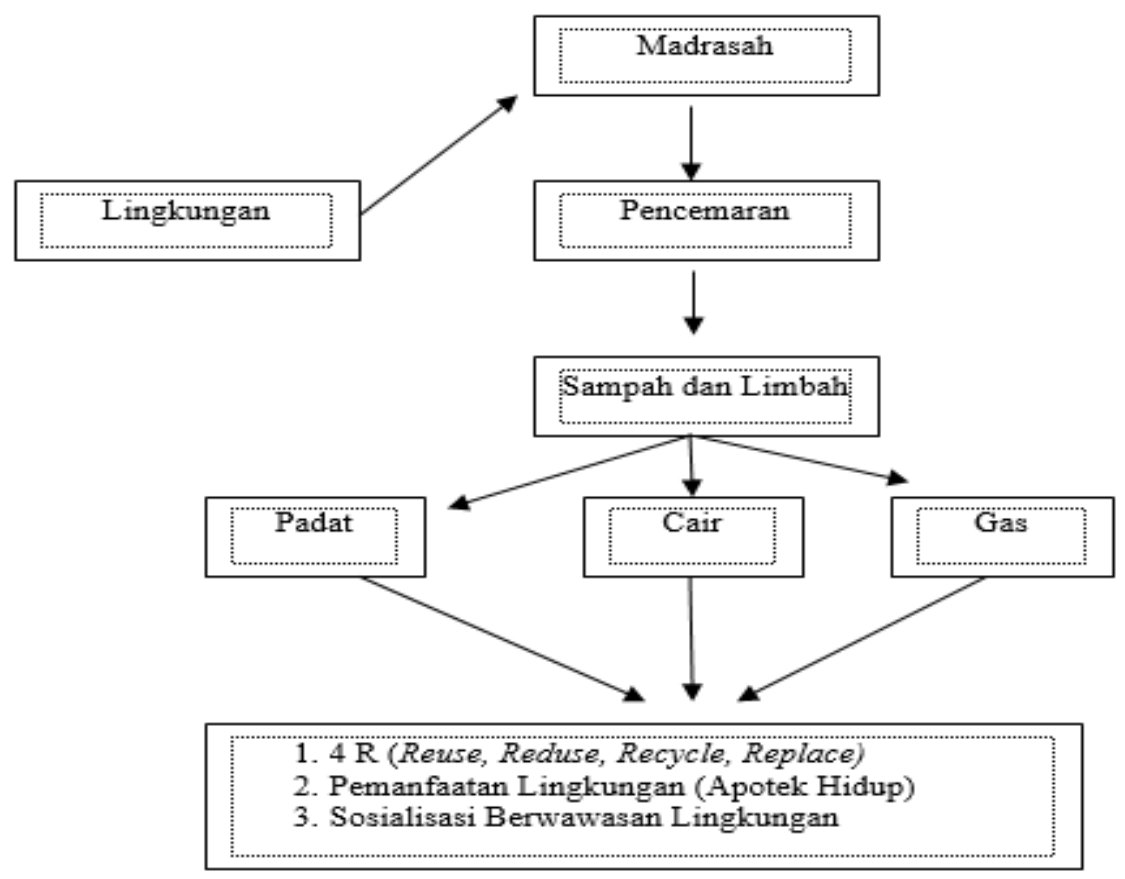

Kegiatan pengabdian kepada masyarakat pada madrasah binaaan dilaksanakan di Madrasah Aliyah NW Mercapada Selat Narmada Kabupaten Lombok Barat NTB. Kegiatan tersebut berlangsung pada 15 Oktober 2016 melalui kegiatan sosialisasi dan manajemen sampah serta limbah yang di hasilkan di lingkungan Madrasah Aliyah NW Mercapada Selat Narmada Kabupaten Lombok Barat.

\section{Pelatihan Manajemen Sampah dan Limbah}

Sampah dan limbah yang dihasilkan dalam suatu kegiatan seperti kegiatan belajar mengajar harus diminimalisir kuantitasnya, karena jika dibiarkan terus menerus akan mengganggu berbagai aspek. Seperti kebersihan, kesehatan dan keindahan lingkungan. Dengan demikian akan menyebabkan turunnya kualitas hidup manusia.

Sampah pada dasarnya merupakan suatu bahan yang terbuang atau di buang dari suatu sumber hasil aktivitas manusia maupun proses-proses alam yang tidak mempunyai nilai ekonomi, bahkan dapat mempunyai nilai ekonomi yang negatif karena dalam penanganannya baik untuk membuang atau membersihkannya memerlukan biaya yang cukup besar. 
Sampah adalah bahan yang tidak mempunyai nilai atau tidak berharga untuk maksud biasa atau utama dalam pembikinan atau pemakaian barang rusak atau bercacat dalam pembikinan manufktur atau materi berkelebihan atau ditolak atau buangan (Kementerian Lingkungan Hidup, 2005). Dalam Undang-Undang No.18 tentang Pengelolaan Sampah dinyatakan definisi sampah sebagai sisa kegiatan sehari-hari manusia dan/atau dari proses alam yang berbentuk padat.

Salah satu cara yang dapat dilakukan adalah dengan memanajemen sampah dan limbah yang dihasilkan. Misalnya membuat kerajinan yang berbahan dasar sampah, membuat kompos dari sampah organik, membuat bak sampah atau tong sampah berdasarkan jenisnya dan membuat tampungan limbah cair dan padat yang dihasilkan untuk dijadikan pupuk organik cair maupun pupuk organik padat dengan bantuan Mikroorganisme.

Sedangkan cara sederhana untuk mengolah limbah padat dan cair yang dihasilkan dalam aktifitas belajar mengajar di sebuah madrasah adalah dengan membuat alat komposter sederhana dengan memanfaatkan alat dan bahan sederhana yang ada di sekitar lingkungan madrasah. Dengan adanya alat komposter ini akan membantu mengurangi dampak dari limbah cair dan limbah padat yang dihasilkan. Seperti bau yang tidak sedap atau bau pesing (air seni/air kencing/urin) dan bau dari buangan sisa makanan di selokan air.

Proses pengolahan limbah cair dan padat menjadi pupuk organik baik cair maupun padat akan lebih cepat dengan bantuan mikroorganisme tambahan yang sudah beredar di pasaran (contohnya produk EM4) serta menambah unsur-unsur yang ada di dalam pupuk organik yang dihasilkan. Seperti unsur N, P, dan K yang dibutuhkan oleh tumbuhan atau tanaman budidaya lainnya.

Manajemen sampah dan limbah juga dapat dilakukan dengan menerapkan prinsip-prinsip 4R, yaitu dengan cara:

1. Reuse adalah menggunakan kembali barang-barang yang dapat di pakai kembali. Misalnya memakai barang bekas seperti ember bekas dan sejenisnya sebagai tempat sampah atau komposter.

2. Reduse adalah mengurangi penggunaan barang atau material yang menghasilkan sampah. Seperti penggunaan kantong plastik, membeli minuman ringan yang memakai material plastik. Hal ini memang sulit, karena penggunaan plastik memberikan kemudahan, kepraktisan bagi manusia. Akan tetapi jika 
jumlahnya terus menerus meningkat, akan menyebabkan permasalahan lingkungan.

3. Recycle yaitu dengan mendaur ulang sampah yang ada, baik sampah organik maupun plastik menjadi sesuatu yang lebih bermanfaat atau bernilai ekonnomi. Misalnya dengan membuat kerajinan berbahan dasar sampah. Membuat pupuk organik dari sampah organik.

4. Replace yaitu mengganti barang yang sekali pakai dengan barang yang dapat dipakai berkali-kali. Misalnya dengan hal yang sangat sederhana, yaitu menggunakan botol air minum yang dijual di pasaran. Hal sederhana tersebut, berkontribusi untuk meminimalisir jumlah sampah plastik yang ada di lingkungan.

\section{PENUTUP}

Kegiatan pengabdian masyarakat khususnya pada kegiatan pengabdian madrasah binaan diharapkan mampu menjadi salah satu solusi dalam menghadapi permasalahan lingkungan yang terjadi terutama permasalahan lingkungan yang terjadi di lingkungan madrasah seperti permasalahan sampah dan limbah yang dihasilkan selama kegiatan belajar mengajar.

Diharapkan kegiatan pengabdian masyarakat khususnya pada kegiatan pengabdian madrasah binaan terus ditingkatkan sehingga permasalahan lingkungan yang ada di Pulau Lombok secara khususnya dan Indonesia secara umumnya dapat diminimalisir terutama yang bersumber dari sampah dan limbah.

\section{DAFTAR PUSTAKA}

Budiastuti, S., Ekologi Umum Teori Dasar Pengelolaan Lingkungan. Solo: UNS Press. 2010.

Erwati, A., Upaya Pelestarian Lingkungan Hidup.Yogyakarta: Pustaka Pelajar, 2013.

Fahruddin, Bioteknologi lingkungan. Bandung: Alfabeta, 2010.

Fauzi, A., Ekonomi Sumberdaya Alam dan Lingkungan. Jakarta: Gramedia Pustaka Utama, 2004.

Fitri. R., Diktat Kegiatan Lapangan Pemberdayaan Masyarakat. Teknologi Proses Pengolahan Tahu dan Pemanfaatan Limbahnya. Yogyakarta: Universitas Negeri Yogyakarta, 2013. 
Nurdiana, Pemberdayaan Masyarakat Dalam...

Ginting P, Sistem Pengelolaan Linkungan dan Limbah Industri. Bandung: Yrama Widya, 2007.

Handayani, R., Pengantar Hukum Lingkungan. Surakarta: Cakra Books, . 2011.

Jasmiati, Jurnal Ilmu Lingkungan. Bioremidiasi Limbah Cair Industri Tahu Menggunakan Efektif Mikroorganisme (EM4), universitas Riau Pekanbaru. Jurnal Ilmu Lingkungan Vol. 2 (4), 2010.

Kementerian Lingkungan Hidup, Teologi Lingkungan Etika Pengelolaan Lingkungan dalam Perspektif Islam. Yogyakarta: PP Muhamadiyah, 2011.

Kementerian Lingkungan Hidup, Undang-Undang Republik Indonesia Nomor 32 Tahun 2009 tentang Perlindungan dan Pengelolaan Lingkungan Hidup. Jakarta Timur: Deputi MENLH, 2011.

Keraf, A. S, Etika Lingkungan. Jakarta: Buku Kompas, 2002.

Maya. N., The Jurnal Environmental Education. Environmental Problems, Causes and Solutions: and Open Questions, Taylor \& Francis group. 41(2) 101-115, 2010.

Michael. J. P., Dasar-Dasar Mikrobiologi Jilid I. Jakarta: UI-Press, 2008.

Mulia M, Kesehatan Lingkungan. Yogyakarta: Graha Ilmu, 2005.

Nita. D, Kajian produksi selulosa mikrobial melalui dua tahap kultivasi. Bogor: IPB, 2012.

Hidayat, Nur, Mikrobiologi Industri.Malang: Universitas Brawijaya, 2008.

Page, D.S., Prinsip-Prinsip Biokimia. Erlangga: Jakarta, 1997.

Rohadi T., Budaya Lingkungan Akar Masalah dan Solusi Krisis Lingkungan. Yogyakarta: Ecologia Press, 2011.

Sastrawijaya, T., Pencemaran Lingkungan. Jakarta: PT Rineka Cipta, 2009.

Setyono, P., Cakrawala Memahami Lingkungan. Solo: UNS Press, 2008. Etika, Moral, Dan Bunuh Diri Lingkungan Dalam Perspektif Ekologi (Solusi Berbasis ental Insight Quotient-EIQ. Solo: Sebelas Maret University Press, 2011.

Silvana. S, Perencanaan Sistem, Jakarta: Universitas Indonesia, 2009. 